\title{
Pengaruh Ketinggian Tempat Terhadap Respon Termoregulasi Kambing Peranakan Etawah (PE)
}

\author{
(Effect of Altitude on Thermoregulatory Response of Etawah Grade Goat) \\ Diana $^{1}$, Bagus P. Purwanto ${ }^{2}$, Afton Atabany ${ }^{3}$ \\ dianawae77@yahoo.com \\ 1 Mahasiswa Pascasarjana Institut Pertanian Bogor email : \\ 2 Program Diploma, Institut Pertanian Bogor \\ 3 Dosen Departemen Ilmu Produksi dan Teknologi Peternakan, Fakultas Peternakan IPB
}

\begin{abstract}
Abstrak
Kambing peranakan Etawah (PE) dapat dipelihara pada berbagai kondisi lingkungan. Penelitian ini bertujuan membandingkan respon termoregulasi kambing PE yang dipelihara pada ketinggian tempat yang berbeda (200, 400 dan $600 \mathrm{~m}$ dpl). Suhu lingkungan (Ta), kelembaban udara (Rh) dan kecepatan angin (Va) diukur selama 12 jam setiap 1 jam yang dimulai pada pukul 06.00-18.00 WIB. Respon termoregulasi ternak terdiri atas suhu rektal (Tr), frekuensi pernafasan (Rr) dan denyut jantung (Hr) diukur setiap hari pada pukul 06.00, 12.00 dan 18.00 WIB. Data yang diperoleh dianalisis menggunakan uji-t dua sampel independent dan analisis regresi. Hasil penelitian menunjukkan bahwa ketinggian tempat 200, 400 dan 600 $\mathrm{m}$ dpl berpengatuh nyata $(\mathrm{P}<0,05)$ terhadap suhu lingkungan, rataan suhu lingkungan masing-masing adalah $30,16 \pm 2,88 ; 27,73 \pm 2,45$ dan $26,63 \pm 2,91^{\circ} \mathrm{C}$. Namun kelembaban dan kecepatan angin tidak berbeda nyata $(\mathrm{P}>0,05)$. Ketinggian tempat berpengaruh nyata $(\mathrm{P}>0,05)$ terhadap suhu rektal dan denyut jantung, tetapi tidak berpengaruh terhadap laju respirasi. Kambing PE merasa lebih nyaman untuk dipelihara pada ketinggian $400 \mathrm{~m}$ dpl.
\end{abstract}

Kata kunci : ketinggian, kambing peranakan etawah, respon termoregulasi

\begin{abstract}
Etawah grade does were kept in different environment. Current research was conducted to compare the thermoregulatory response of Etawah grade goat which were kept at 200, 400 and $600 \mathrm{~m}$ asl. Measured environmental factors were temperature (Ta), relative humidity $(\mathrm{Rh})$, and air velocity (Va) were measured for 12 hours from $06.00 \mathrm{am}$ to $06.00 \mathrm{pm}$. Thermoregulatory response included rectal temperature $(\mathrm{Tr})$, respiration rate $(\mathrm{Rr})$ and heart rate $(\mathrm{Hr})$ were measured every day at $6 \mathrm{am}, 12 \mathrm{am}$ and $6 \mathrm{pm}$. Data obtained were analyzed statistically using independent two-sample T-Test and regression analysis. The results showed different altitude 200, 400 and $600 \mathrm{~m}$ asl significantly affected $(\mathrm{P}<0.05)$ ambient temperature, which were average $30,16 \pm 2,88 ; 27,73 \pm 2,45$ and $26,63 \pm 2,91$; respectively. Otherwise, different altitude did not affect humidity and air velocity. Altitude significantly affected $(\mathrm{P}<0.05)$ rectal temperature and heart rate, but did not affect respiration rate. Etawah grade goat were comfortable to kept in $400 \mathrm{~m}$ asl.
\end{abstract}

Keyword : altitude, Etawah grade goat, thermoregulation response

Diana, Bagus P Purwanto, dan Afton Atabany 


\section{PENDAHULUAN}

Kambing PE termasuk dari kambing perah yang terdapat di Indonesia. Kambing PE merupakan hasil kawin tatar (grading-up) antara kambing Kacang (kambing lokal) dengan kambing Etawah, sehingga mempunyai sifat diantara tetuanya (Atabany 2001). Persilangan kambing PE dilakukan untuk memperbaiki mutu kambing lokal dan sekarang keturunannya sudah mampu beradaptasi dengan lingkungan Indonesia. Produksi susu yang dihasilkan kambing PE adalah 0.452-2.2 $\mathrm{kg}$ hari $^{-1}$ dengan masa laktasi cukup beragam yaitu 92-256 hari dengan rataan 156 hari (Sodiq dan Abidin 2009).

Variasi produksi tersebut disebabkan oleh adanya variasi dalam pemeliharaan. Pada umumnya kambing PE di Indonesia dipelihara mulai dari daerah/dataran rendah sampai dataran tinggi. Variasi lain dalam pemeliharaan, selain faktor tersebut adalah banyaknya variasi dalam pemberian pakan.

Variasi dalam pemberian pakan, secara umum pada ternak akan menyebabkan perbedaan respon fisiologis, salah satunya respon jantung yang sudah diamati untuk melihat variasi pakan dan lingkungan adalah respon termoregulasi.

Perbedaan ketinggian tempat mempengaruhi respon termoregulasi terutama suhu rektal. Kambing PE yang dipelihara pada ketinggian $600 \mathrm{~m}$ dpl memiliki respon termoregulasi lebih tinggi. Hal ini diduga disebabkan oleh suhu lingkungan yang rendah dan kelembaban yang tinggi sehingga ternak mengkonsumsi pakan lebih banyak yang dapat mengatur keseimbangan metebolisme tubuh sehingga menyebabkan respon termoregulasi meningkat.

Berdasarkan uraian tersebut, maka perlu dilakukan penelitian untuk mengetahui pengaruh suhu lingkungan akibat perbedaan ketinggian tempat dan konsumsi pakan terhadap respon termoregulasi kambing PE yang dipelihara pada lokasi yang berbeda.

\section{Materi dan Metode}

Penelitian dilakukan di tiga peternakan kambing peranakan Etawah (PE) yang dibedakan berdasarkan ketinggian tempat di kota dan kabupaten Bogor. Ketiga peternakan tersebut adalah:

1. Peternakan yang berada pada ketinggian $400 \mathrm{~m}$ dpl.

2. Peternakan yang berada pada ketinggian $600 \mathrm{~m} \mathrm{dpl}$

Pengumpulan data penelitian dilaksanakan pada bulan Apri - Mei 2014. Penelitian menggunakan kambing Peranakan Etawah (PE) betina laktasi sebanyak 8 ekor pada masing-masing ketinggian 400 dan $600 \mathrm{~m}$ dpl.

Faktor lingkungan yang diukur yaitu suhu lingkungan (Ta), kelembaban udara (Rh), dan kecepatan angin (Va). Suhu lingkungan, kelembaban udara dan kecepatan angin diukur selama 12 jam, setiap jam mulai pukul 06.00-18.00 WIB. Respons termoregulasi ternak yang diukur suhu rektal (Tr), frekuensi pernafasan (Rr), denyut jantung (Hr), diukur setiap hari pada pukul 06.00, 12.00 dan 18.00 WIB.

\section{Pengukuran Konsumsi Pakan}

Konsumsi pakan diukur dengan menghitung jumlah pemberian pakan ekor $^{-1}$ hari $^{-1}$ dan jumlah pakan yang tersisa ekor $^{-1}$ hari $^{-1}$ dalam gram. Pengukuran konsumsi pakan dilakukan pada setiap pemberian pakan dengan menggunakan timbangan pakan yang digunakan di masing-masing kondisi.

Diana, Bagus P Purwanto, dan Afton Atabany 


\section{Analisis Data}

Data hasil pengukuran terhadap respon termoregulasi dan kondisi lingkungan dianalisis dengan menggunakan uji t dua sampel independent (tidak berpasangan) dengan persamaan sebagai berikut (Steel dan Torrie 1995): $\mathrm{t}=\frac{r s \sqrt{n-2}}{\sqrt{1-r s 2}}$

Keterangan :

$\mathrm{n} \quad=$ jumlah data

$\mathrm{r} \quad \quad=$ koefisien korelasi

Hubungan antara suhu lingkungan dan respon termoregulasi pada kambing PE dihitung menggunakan regresi linier sederhana dengan persamaan sebagai berikut (Gasperz 1999):

$$
\mathrm{Y}=\mathrm{a} \mathrm{X}^{\mathrm{b}}
$$

Keterangan :

$\mathrm{y} \quad=$ variabel terikat / tidak bebas (Suhu rektal, denyut jantung, laju respirasi)

$\mathrm{x} \quad=$ variabel bebas (Suhu lingkungan)

$\mathrm{b} \quad=$ koefisien regresi

a $\quad=$ koefisien determinasi

\section{HASIL DAN PEMBAHASAN}

\section{Kondisi Lingkungan dan Respon Termoregulasi}

Kambing merupakan ternak homoetermik yang berusaha mempertahankan suhu tubuhnya pada kondisi lingkungan berbeda. Hasil pengukuran kondisi lingkungan dan respon termoregulasi kambing Peranakan Etawah (PE) disajikan pada Tabel 1.

Berdasarkan hasil rata-rata kondisi lingkungan diketahui bahwa ketinggian tempat berpengaruh nyata $(\mathrm{P}<0.05)$ terhadap suhu lingkungan, namun tidak memberikan pengaruh terhadap kelembaban dan kecepatan angin. Variasi harian suhu lingkungan selama penelitian dapat dilihat pada Gambar 1. Liem (2004) menyatakan bahwa daerah dengan ketinggian 100-450 m dpl dapat dikategorikan dalam daerah ketinggian sedang yang memiliki suhu yang relatif normal dengan kelembaban yang stabil, sedangkan pada daerah diatas $450 \mathrm{~m}$ dpl merupakan daerah tinggi yang memiliki suhu relatif rendah dengan kelembaban yang tinggi. Suhu dan kelembaban yang tinggi akan menyebabkan turunnya produktivitas kambing perah (Smith dan Mangkuwidjojo 1988).

Rataan suhu dan kelembaban udara dalam penelitian ini masih berada dalam kisaran nyaman bagi kambing. Suhu udara nyaman bagi kambing berkisar antara 18 sampai $30^{\circ} \mathrm{C}$. Secara umum kisaran rentang suhu dan kelembaban dalam penelitian ini hampir sama dengan suhu dan kelembaban di Indonesia pada umumnya berkisar $24-34{ }^{\circ} \mathrm{C}$ dengan kelembaban $60-90 \%$.

Ketinggian tempat berpengaruh nyata $(\mathrm{P}<0.05)$ terhadap suhu rektal dan denyut jantung kambing PE, namun tidak berpengaruh terhadap laju respirasi antara kambing PE di ketinggian 400 dan $600 \mathrm{~m}$ dpl. Suhu rektal kambing PE yang dipelihara pada ketinggian 400 dan $600 \mathrm{~m}$ dpl masih dalam kisaran normal. Yusuf (2007) menyatakan bahwa suhu rektal normal kambing berkisar 38.5-40 ${ }^{\circ} \mathrm{C}$. Al-Tamimi (2007) juga menyatakan bahwa suhu rektal normal kambing adalah 38.3-39 ${ }^{\circ} \mathrm{C}$ dan merupakan indikator yang paling

Diana, Bagus P Purwanto, dan Afton Atabany 
umum dari suhu tubuh dan dianggap sebagai refleksi dari suhu tubuh dan parameter fisiologis yang menunjukkan tingkat kesejahteraan hewan di lingkungan yang panas.

Hasil analisis statistik menunjukkan bahwa ketinggian tempat tidak berpengaruh nyata terhadap laju respirasi ( $\mathrm{P}>0.05)$. Hal ini disebabkan pada ketinggian 400 dan $600 \mathrm{~m}$ dpl suhu udara dan kelembaban masih dalam kisaran yang dapat ditolerir oleh kambing PE. Kurihara dan Shioya (2003) menyatakan bahwa pada saat suhu dan kelembaban lingkungan pada $28{ }^{\circ} \mathrm{C}-40 \%$ atau $28{ }^{\circ} \mathrm{C}-80 \%$, maka suhu tubuh dan frekuensi pernafasan yang terjadi dalam kondisi normal. Silanikove (2000) menyatakan bahwa pengukuran laju respirasi dapat memberikan informasi untuk mengetahui tingkat stres pada ternak (rendah : 40-60 kali/menit, sedang: 60-80 kali/menit, tinggi: 80-120 kali/menit dan stres panas yang parah di atas 150 kali/menit). Okourwa et al. (2013) juga menyatakan bahwa peningkatan laju respirasi $12-20 \mathrm{kali} / \mathrm{menit}$ menunjukkan kambing telah mengalami stres panas.

Tabel 1 Kondisi Lingkungan, Respon Termoregulasi, Konsumsi Pakan, Produksi dan Kualitas Susu Kambing Peranakan Etawah yang Dipelihara pada Ketinggian Tempat Berbeda

\begin{tabular}{|c|c|c|c|}
\hline \multirow{2}{*}{ Peubah } & & \multicolumn{2}{|c|}{ Ketinggian (m dpl) } \\
\hline & & 400 & 600 \\
\hline Kondisi Lingkungan & $:$ & & \\
\hline Suhu $\left({ }^{\circ} \mathrm{C}\right)$ & & $27.73 \pm 2.45^{\mathrm{a}}$ & $26.63 \pm 2.91^{\mathrm{a}}$ \\
\hline Kelembaban (\%) & & $73.5 \pm 8.70$ & $72.4 \pm 11.29$ \\
\hline Kecepatan angin $\left(\mathrm{m} \mathrm{s}^{-1}\right)$ & & $0.10 \pm 0.17 \mathrm{z}$ & $0.04 \pm 0.12$ \\
\hline Respon Termoregulasi & $:$ & & \\
\hline Suhu Rektal $\left({ }^{\circ} \mathrm{C}\right)$ & & $38.35 \pm 0.8^{b}$ & $38.51 \pm 0.4^{\mathrm{a}}$ \\
\hline Denyut jantung (kali menit ${ }^{-1}$ ) & & $68 \pm 11.3^{\mathrm{b}}$ & $77 \pm 8.4^{\mathrm{a}}$ \\
\hline Laju respirasi (kali menit $\left.{ }^{-1}\right)$ & & $49 \pm 11.0^{\mathrm{a}}$ & $48 \pm 16.9^{\mathrm{a}}$ \\
\hline Konsumsi Pakan (g ekor ${ }^{-1}$ hari $^{-1}$ ) & : & & \\
\hline Bahan kering & & $550.68 \pm 68.99 b$ & $1460.27 \pm 127.17 \mathrm{a}$ \\
\hline Protein kasar & & $69.98 \pm 1.68 b$ & $158.50 \pm 15.99 a$ \\
\hline Produksi dan kualitas susu & : & & \\
\hline Produksi susu 1 hari $^{-1}$ & & $0.413 \pm 0.0 \mathrm{~b}$ & $1.254 \pm 0.42 \mathrm{a}$ \\
\hline Berat jenis $\left(\mathrm{g} \mathrm{ml}^{1}{ }^{1}\right)$ & & $1.033 \pm 0.09$ & $1.028 \pm 0.02$ \\
\hline Bahan kering $(\%)$ & & $15.05 \pm 1.98 \mathrm{a}$ & $13.24 \pm 2.5 b$ \\
\hline Lemak $(\%)$ & & $6.19 \pm 1.14 \mathrm{a}$ & $4.43 \pm 1.74 b$ \\
\hline BKTL (\%) & & $8.86 \pm 0.58$ & $8.81 \pm 0.76$ \\
\hline Protein $(\%)$ & & $4.20 \pm 0.87$ & $4.06 \pm 0.71$ \\
\hline
\end{tabular}

Keterangan: Nilai pada kolom yang sama yang diikuti huruf yang berbeda menunjukkan perbedaan yang nyata $(\mathrm{P}<0.05)$ 


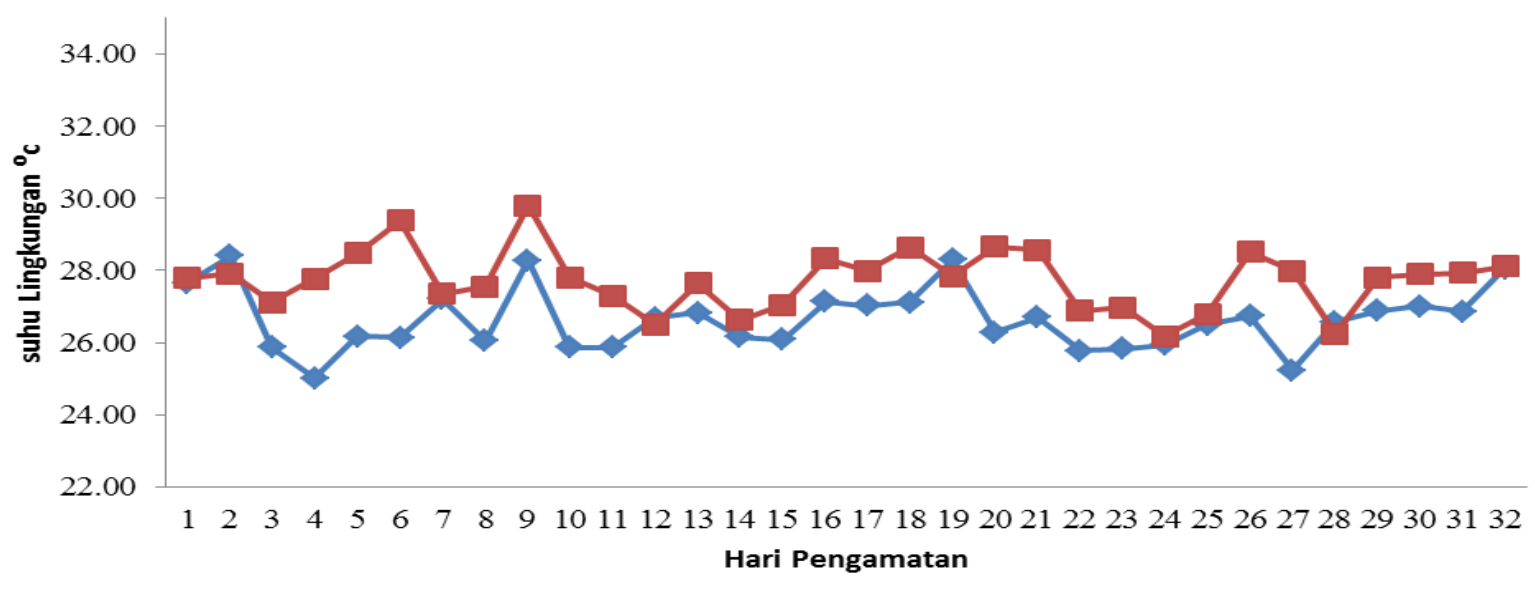

Gambar 1 Kondisi harian suhu lingkungan pada ketinggian 400 (•) dan 600 m dpl (४)

Frekuensi denyut jantung kambing PE yang dipelihara di ketinggian 400 dan $600 \mathrm{~m}$ dpl memiliki nilai rataan masing-masing adalah $68 \pm 11.3$ dan $77 \pm 8.4$ kali menit $^{-1}$. Hasil analisis statistik menunjukkan bahwa ketinggian tempat berpengaruh nyata $(\mathrm{P}<0.05)$ terhadap frekuensi denyut jantung. Frekuensi denyut jantung kambing PE dalam penelitian ini masih dalam kisaran normal, seperti dinyatakan oleh Duke's (1995), bahwa Frekuensi denyut jantung kambing normal berkisar 70-80 kali/menit.

\section{Konsumsi Bahan Kering}

Penentuan konsumsi pada ternak ruminansia didasarkan pada bahan kering, hal ini disebabkan kandungan air dari berbagai macam pakan sangat bervariasi. Konsumsi pakan pada kambing selama periode laktasi lebih banyak ditujukan untuk memproduksi susu.

Hasil analisis statistik menunjukkan bahwa ketinggian tempat 400 dan $600 \mathrm{~m}$ dpl berpengaruh nyata $(\mathrm{P}<0.05)$ terhadap konsumsi BK dan protein kasar. Kambing PE yang dipelihara pada ketinggian 600 m dpl memiliki rataan komsumsi BK cenderung lebih tinggi yaitu 1460.27 g/ekor/hari dibandingkan dengan kambing PE yang dipelihara pada ketinggian tempat $400 \mathrm{~m}$ dpl yaitu $550.68 \mathrm{~g} / \mathrm{ekor} / \mathrm{hari}$. Jumlah konsumsi ini lebih rendah dibandingkan penelitian Winarni (2014) pada ransum kontrol yaitu 1672 g/ekor/hari dan penelitian Atabani (2001) konsumsi bahan kering harian kambing PE pada penelitiannya di peternakan Barokah (720 m dpl) adalah 1759 g/ekor/hari. Menurut NRC (1981), kebutuhan konsumsi BK dan protein kasar kambing dengan berat hidup $50 \mathrm{~kg}$ dengan kadar lemak susu 5.0-6.0\% adalah 0.886$0.895 \mathrm{~kg}$ bahan kering dan 0.517-0.165 kg protein kasar. Perbedaan konsumsi BK ini diduga disebabkan oleh ketinggian tempat yang yaitu suhu lingkungan. Suhu lingkungan akan sangat mempengaruhi konsumsi pakan ternak. Jika dilihat dari sisi konsumi pakan dan penggunaan pakan yang dikonsumsi ternak, maka dinyatakan bahwa pakan yang dimakan oleh ternak akan diubah menjadi energi dan panas metabolisme melalui proses metabolisme dalam tubuh ternak. Kondisi suhu lingkungan yang rendah, 
ternak akan berusaha menyeimbangkan produksi panas, pada kondisi ini konsumsi pakan oleh ternak akan semakin meningkat dan begitu juga sebaliknya pada kondisi suhu lingkungan tinggi akan menurunkan konsumsi pakan. Suhu lingkungan yang tinggi cenderung menekan nafsu makan dan produktivitas dan respon penyesuaian ini terjadi pada kambing, karena konsumsi pakan dan produksi panas berkaitan, temperatur yang meningkat menyebabkan komsumsi pakan menurun, yang dapat mengurangi produksi panas (Devendra 1994).

Peningkatan produksi susu dapat dilihat dari peningkatan konsumsi pakan dalam bentuk bahan kering dan protein yang terkandung di dalam bahan pakan yang disintesa menjadi zat - zat nutrient dalam darah dan terjadi penyerapan yang dapat meningkatkan produksi susu dan kadar protein serta lemak dalam susu (Mc Donald et al. 2002).

\section{Produksi Susu dan Kualitas Susu Kambing PE}

Kuantitas dan kualitas pakan yang diberikan pada seekor ternak perah merupakan salah satu faktor yang sangat menentukan optimalitas produksi susu dan komposisi susu selama laktasi. Produksi dan kualitas susu kambing PE dalam penelitian ini disajikan pada Tabel 1.

Produksi susu kambing PE yang dipelihara pada ketinggian 400 dan $600 \mathrm{~m}$ dpl berpengaruh nyata $(\mathrm{P}<0.05)$ terhadap produksi susu. Berdasarkan hasil analisis statistik, produksi susu tertinggi pada ketinggian $600 \mathrm{~m}$ dpl $\left(1.254 \pm 0.42 \mathrm{~L} \mathrm{ekor}^{-1}\right.$ hari $\left.^{-1}\right)$ sedangkan diketinggian $400 \mathrm{~m}$ dpl $\left(0.413 \pm 0.09 \mathrm{~L} \mathrm{ekor}^{-1}\right.$ hari $\left.^{-1}\right)$. Produksi susu yang dihasilkan berbeda diduga akibat perbedaan suhu lingkungan, konsumsi BK dan masa laktasi .

Peningkatan produksi susu dapat dilihat dari peningkatan konsumsi pakan dalam bentuk bahan kering (BK) dan protein kasar yang terkandung dalam bahan pakan yang disintesa menjadi zat-zat nutrient dalam darah dan terjadi penyerapan yang dapat meningkatkan produksi susu dan kadar protein serta lemak dalam susu ((McDonald et al. 2002). Ketinggian tempat berbeda nyata $(\mathrm{P}<0.05)$ terhadap konsumsi bahan kering dan protein kasar pakan pada ketinggian 400 dan $600 \mathrm{~m}$ dpl. Berdasarkan NRC (1981) diketahui bahwa kambing laktasi dengan bobot badan 50 dan $60 \mathrm{~kg}$ membutuhkan bahan kering pakan masingmasing adalah 2400 dan $2600 \mathrm{~g}$ sehingga dalam penelitian ini dapat dikatakan bahwa konsumsi BK belum terpenuhi.

Berat jenis susu adalah perbandingan antara berat bahan tersebut dengan berat air pada volume dan suhu yang sama. Faktor-faktor yang mempengaruhi perubahan berat jenis susu adalah faktor komposisi susu itu sendiri, yang terdiri dari protein, lemak, laktosa, gas dan mineral dalam susu (Eckles et al. 1957). Rataan berat jenis susu pada ketinggian400 dan $600 \mathrm{~m}$ dpl adalah 1.033 dan $1.028 \mathrm{~g} \mathrm{ml}^{-1}$. Hasil serupa dilaporkan oleh Edelsten (1988) yaitu berat jenis susu kambing bervariasi antara 1.0260 sampai 1.420 . Ketinggian tempat berpengaruh nyata $(\mathrm{P}<0.05)$ terhadap berat jenis susu kambing PE pada ketinggian 400 dan 600 m dpl. Adnan (1984) menyatakan berat jenis susu dipengaruhi oleh kadar lemak, protein, laktosa dan mineral-mineral yang terlarut di dalam susu tersebut. Umumnya di dalam suatu larutan, semakin banyak senyawa-senyawa yang terlarut di dalamnya, maka semakin besar pula berat jenisnya. Berat jenis susu dipengaruhi oleh senyawa yang terlarut di dalamnya. Berat jenis susu erat kaitannya dengan komponen padatan susu dan bahan kering dalam ransum. Hal ini disebabkan pada ketinggian $400 \mathrm{~m}$ dpl bahan kering susu lebih tinggi dibandingkan ketinggian $600 \mathrm{~m}$ dpl. Bahan kering susu dipengaruhi oleh

Diana, Bagus P Purwanto, dan Afton Atabany 
kadar lemak susu dan BKTL pada masing-masing ketinggian. Adriani (2003) menyatakan, berat jenis susu ditentukan oleh kandungan bahan kering susu, sehingga perbedaan kandungan bahan kering menyebabkan perbedaan berat jenis. Menurut standar Thailand Agricurtural Standar (TAS) tentang kualitas susu kambing segar No 6006 (2008) kualitas dari standar berat jenis adalah >1.028 sehingga susu yang digunakan dalam penelitian ini memenuhi syarat susu segar kambing.

Hasil analisis statistik menunjukkan bahwa ketinggian tempat berpengaruh nyata $(\mathrm{P}<0.05)$ terhadap kadar lemak susu. Kadar lemak susu kambing PE yang dipelihara pada ketinggian $400 \mathrm{~m}$ dpl lebih tinggi dibandingkan ketinggian $600 \mathrm{~m}$ dpl. Hal ini diduga disebabkan kambing PE yang dipelihara pada ketinggian $400 \mathrm{~m}$ dpl lebih banyak mengkonsumsi hijauan dan menghasilkan peroduksi susu yang rendah. Mukhtar (2006) menyatakan bahwa saat produksi susu meningkat, kadar lemak dan kadar protein susu akan menurun sedangkan saat produksi susu menurun, kadar lemak dan kadar protein susu meningkat. Dengan demikian, terdapat korelasi yang negatif antara produksi susu dengan kadar lemak susu.Tyler dan Ensminger (2006) juga menyatakan bahwa tingginya proporsi hijauan dalam pakan ternak perah menyebabkan peningkatan kadar lemak susu yang dihasilkan. Kadar lemak dipengaruhi oleh asam asetat yang berasal dari hijauan (Ace dan Wahyuningsih, 2010 dan Ramadhan et al., 2013).

Kadar bahan kering tanpa lemak adalah bahan kering dikurangi dengan kadar lemak (Saleh, 2004). Hasil analisis statistik menunjukkan bahwa ketinggian tempat tidak berpengaruh nyata terhadap kadar bahan kering tanpa lemak (BKTL) susu kambing PE. Kadar BKTL susu kambing PE yang dipelihara pada ketinggian 400 dan $600 \mathrm{~m}$ dpl masing-masing adalah $8.86 \pm 0.58$ dan $8.81 \pm 0.76 \%$.

Ketinggian tempat tidak berpengaruh nyata terhadap kadar protein susu kambing. Rataan kadar protein susu kambing masing-masing adalah 4.66 $\pm 0.26,4.20 \pm 0.87$ dan 4.06 \pm 0.71 . Berdasarkan Thailand Agricultural Standard No 6006 (2008) tentang susu kambing dalam penelitian ini telah memenuhi standar susu kambing yang ditetapkan. Persentase protein dan lemak dari kualitas susu dalam penelitian ini tergolong sangat baik (premium).

\section{Hubungan antara Kondisi Lingkungan dan Respon Termoregulasi}

Suhu udara dan kelembaban menyebabkan perubahan keseimbangan panas dalam tubuh ternak, keseimbangan air, keseimbangan energi dan keseimbangan tingkah laku ternak. Iklim mikro disuatu tempat yang tidak mendukung bagi kehidupan ternak membuat potensi genetik seekor ternak tidak dapat ditampilkan secara maksimal (McNeilly, 2001). Hasil perhitungan hubungan antara kondisi suhu lingkungan dan respon termoregulasi kambing PE disajikan pada Tabel 2 dan perubahan suhu lingkungan dan respon termoregulasi kambing PE dapat dilihat pada Gambar 2.

Hasil analisis regresi linier pada suhu rektal menunjukkan bahwa koefisien regresi pada ketinggian 200, 400 dan $600 \mathrm{~m}$ dpl adalah 0.07, 0.05 dan 0.03. Koefisien regresi pada ketinggian $200 \mathrm{~m}$ dpl lebih tinggi dibandingkan ketinggian 400 dan $600 \mathrm{~m}$ dpl. Suhu lingkungan mempengaruhi suhu rektal dilihat dari koefisien determinan $\left(\mathrm{R}^{2}\right)$ yaitu 0.93 atau 93\% suhu rektal dipengaruhi suhu lingkungan sisanya $7 \%$ dipengaruhi faktor lain.

Diana, Bagus P Purwanto, dan Afton Atabany 
Tabel 2 Koefisien determinan $\left(\mathrm{R}^{2}\right)$ antara suhu lingkungan (Ta) dengan respon termoregulasi kambing PE

\begin{tabular}{ccc}
\hline Ketinggian $(\mathrm{m} \mathrm{dpl})$ & Persamaan Regresi & Koefisien determinan $\left(\mathrm{R}^{2}\right)$ \\
\hline Suhu rektal $(\mathrm{Tr}):$ & & 0.74 \\
400 & $3.44 \mathrm{X}^{0.05}$ & 0.68 \\
600 & $3.54 \mathrm{X}^{0.03}$ & \\
Denyut jantung $(\mathrm{Hr}):$ & & 0.98 \\
400 & $2.56 \mathrm{X}^{0.42}$ & 0.76 \\
600 & $3.50 \mathrm{X}^{0.18}$ & \\
Laju respirasi $(\mathrm{Rr}):$ & & 0.90 \\
400 & $0.60 \mathrm{X}^{1.56}$ & 0.64 \\
600 & $2.04 \mathrm{X}^{0.54}$ & \\
\hline
\end{tabular}

Keterangan : Koefisien determinan (R) 2 pada setiap respon termoregulasi yang sama yang diikuti huruf yang berbeda menunjukkan perbedaan yang nyata $(\mathrm{p}<0.05)$

Koefisien regresi di ketinggian $400 \mathrm{~m}$ dpl adalah 0.05, namun $\mathrm{R}^{2} 0.74$ (74\%) suhu rektal dipengaruhi suhu lingkungan sisanya $26 \%$ dipengaruhi faktor lain. Hal ini diduga diengaruhi oleh suhu lingkungan, aktivitas, ukuran tubuh serta menajemen pemeliharaan. Koefisien regresi di ketinggian $600 \mathrm{~m}$ dpl adalah 0.03 , namun $\mathrm{R}^{2} 0.68$ (68\%) suhu rektal dipengaruhi suhu lingkungan sisanya $32 \%$ dipengaruhi faktor lain. Lebih rendah dibanding ketinggian 200 dan $400 \mathrm{~m}$ dpl, karena suhu lingkungan pada ketinggian $600 \mathrm{~m}$ dpl lebih rendah sehingga ternak dapat menyesuaikan suhu rektal. Sesuai dengan pendapat (Purwanto et al. 1995) mengatakan bahwa ternak berhasil melakukan proses termoregulasi atau pengaturan keseimbangan panas melalui mekanisme homeostatis di dalam tubuh yang merupakan perwujudan kerja organ-organ tubuh.

Hasil analisis regresi linier denyut jantung menunjukkan bahwa koefisien regresi pada ketinggian 400 dan $600 \mathrm{~m}$ dpl adalah 0.42 dan 0.18 . Koefisien regresi di ketinggian 400 lebih tinggi dibandingkan ketinggian $600 \mathrm{~m}$ dpl. Dilihat dari $\mathrm{R}^{2}$ yaitu 0.98 artinya $98 \%$ denyut jantung dipengaruhi suhu lingkungan sisanya $2 \%$ dipengaruhi faktor lain. Tingginya $\mathrm{R}^{2}$ dididuga disebabkan oleh suhu lingkungan, ukuran tubuh ternak, aktivitas ternak dan aktivitas pencernaan terutama rumen. Hal ini sesuai dengan pernyataan Utomo et al., (2009) Tingginya frekuensi denyut jantug kemungkinan disebabkan tingginya beban panas dari dalam dan luar tubuh ternak. Pembuangan beban panas terlihat pada peningkatan laju respirasi dan denyut jantung yang merupakan usaha ternak untuk menyeimbangkan produksi panas.

Koefisien regresi denyut jantung diketinggian $600 \mathrm{~m}$ dpl adalah 0.18 lebih rendah di bandingkan ketinggian $400 \mathrm{~m}$ dpl. Dilihat dari $\mathrm{R}^{2} 0.76$ artinya (76\%) suhu lingkungan mempengaruhi denyut jantung, sisanya $24 \%$ dipengaruhi faktor lain. Barkai et al., (2002) melaporkan bahwa terdapat hubungan antara denyut jantung dan matabolisme produksi panas. Selain itu, diketahui bahwa perubahan denyut jantung 
merupakan usaha ternak untuk meminimalkan kehilangan panas dan mempertahan suhu tubuh. Aharoni $e t$ al., (2003) juga melaporkan bahwa penurunan denyut jantung merupakan suatu usaha untuk menurunkan produksi panas tubuh, yang ditunjukkan dengan penurunan konsumsi pakan.

Koefisien regresi laju respirasi diketinggian 400 dan $600 \mathrm{~m}$ dpl adalah 1.56 dan 0.54 . Koefisien regresi di ketinggian $400 \mathrm{~m}$ dpl lebih tinggi dibandingkan keduanya $\mathrm{R}^{2}$ yaitu 0.90 (90\%) artinya 90\% laju respirasi dipengaruhi suhu lingkungan sisanya $10 \%$ dipengaruhi faktor lain. Tingginya $\mathrm{R}^{2}$ diduga disebabkan oleh suhu lingkungan, ukuran tubuh dan aktivitas. Hal ini seperti diutarakan Guyton (1990) menyatakan bahwa perubahan frekuensi pernafasan sejalan dengan peningkatan suhu udara, hal tersebut menyebabkan ternak meningkatkan frekuensi pernafasan untuk melepaskan panas.

Faktor yang dapat mempengaruhi frekuensi pernapasan adalah ukuran tubuh, umur, gerak otot, temperatur lingkungan dan faktor yang disebabkan pengaruh terhadap suhu tubuh ternak yaitu dalam hal produksi panas tubuh. Pada ketinggian $600 \mathrm{~m}$ dpl koefisien regresi 0.54 dengan $\mathrm{R}^{2} 0.64$ (64\%) artinya 64\% laju respirasi dipengaruhi suhu lingkungan, sisanya 36\% dipengaruhi faktor lain. Hal ini diduga disebabkan oleh suhu lingkungan, ukuran tubuh, aktifitas dan kelelahan. Smith dan Mangkuwidjo (1988) laju respirasi bervariasi tergantung dari besar badan, umur, aktivitas tubuh kelelahan dan penuh tidaknya rumen. Peningkatan laju respirasi merupakan suatu usaha untuk meningkatkan evaporasi. Hasil yang sama juga dilaporkan oleh Al-Haidary (2000) dan Sunagawa et al.,(2002) bahwa laju respirasi dan suhu rektal merupakan indikator yang baik untuk menunjukkan stress lingkungan yang diterima oleh ternak.

Suhu lingkungan mempengaruhi laju respirasi. Hasil penelitian menunjukkan kambing yang dipelihara pada suhu $30^{\circ} \mathrm{C}$ memiliki laju respirasi yang lebih tinggi daripada kambing yang dipelihara pada suhu $20{ }^{\circ} \mathrm{C}$ (Sudarman dan Ito 2000). Peningkatan laju respirasi adalah salah satu respon termoregulasi yang menunjukkan peningkatan suhu lingkungan yang bertujuan untuk menghilangkan panas berlebih dan usaha mempertahankan suhu normal tubuh.

\section{KESIMPULAN}

Perbedaan ketinggian tempat $400 \mathrm{~m}$ dpl dan $600 \mathrm{~m}$ dpl mempengaruhi suhu lingkungan, namun tidak mempengaruhi kelembaban dan kecepatan angin. Suhu lingkungan yang berbeda mempengaruhi respon termoregulasi kambing PE. Pada penelitian ini kambing PE lebih nyaman dipelihara pada ketinggian $400 \mathrm{~m}$ dpl, namun untuk menghasilkan produksi susu terbaik pada ketinggian $600 \mathrm{~m}$ dpl.

\section{DAFTAR PUSTAKA}

Aharoni, Y, A. Brosh P. Kourilov A. Ariel A 2003. The variability of the ratio of oxygen consumption to heart rate in cattle and sheep at different hours of the day and under different heat load conditions. Livestock Prod. Sci., 79: 107-17

Al-Haidary A. 2000. Effect of heat stress on some thermoregulatory responses of cattle, sheep and goat. Zag. Vet. J., 28: 101-10

Al-Tamimi HJ. 2007. Thermoregulatory response of goat kids subjected to heat stress. Small Ruminant. Vol 71, Pages 280-285

Atabany A. 2001. Studi kasus produktivitas kambing peranakan Etawah dan kambing Saanen pada peternakan kambing perah Barokah dan PT. Taurus Dairy Farm. Tesis. Sekolah Pascasarjana Fakultas Peternakan. Institut Pertanian Bogor. Bogor (ID). 
Barkai, S., A. Landau, Brosh et al., 2002. Estimation of energy intake from heart rate and energy expenditure in sheep under confinement or grazing condition. Livestock Prod. Sci., 73: 237-46.

Coppock, C.E., Grant, P.A. Portzer, S.J. Charles D.A. Escobosa, A. 1982. Lactating dairy cow responses to dietary sodium, chloride, and bicarbonate during hot weather. J. Dairy Sci. 65: 566-576.

Devendra C, Burn M. 1994. Produksi Kambing di Daerah Tropis. Institut Teknologi Bandung, Bandung (ID).

Duke's. 1970. Physiology of Domestic Animal. Comestock. Assoc, New York :(US)

Duke's. 1995. Physiology of Domestic Animal. Comestock. New York (US) : University Collage, Camel.

Eckles, C. H., combs W. B. and Macy H.. 1957. Milk and Milk Products. Tata McGraw-Hill Publ. Co., Ltd. BoSmbay. New Delhi.

Edelsten, D. 1988. Composition of Milk. In Cross H.R. and A.J. Oversy. Meat Science, Milk Science and Tecnology. Elsivier Science Publishers B.V. Amsterdam, Oxford, New York, Tokyo. pp:137195.

Guyton, A.C. 1990. Fisiologi Kedokteran II. Edisi Ke-5. E.G.C. Penerbit Buku Kedokteran, Jakarta.

Johnson, H.D. 1985. Physiological responses and productivity of cattle. Dalam: Yousef, M.K.

(Ed). Stress Physiology of Livestock. Vol II. CRC Press Inc. Boca Raton, Florida.

Kurihara M \& S Shioya 2003 Dairy Cattle Management In Hot Environment. http//www.fffc.agent.org/library/abstract/eb529.htm. (12 Desember 2014).

Liem 2004. Pengelolaan berbasis birogion .http://www.walhi. or.id/bioregion/nas/peng_basis_bioreg. (27 November 2014).

Mukhtar A. 2006. Ilmu Produksi Ternak Perah. Cetakan 1. Surakarta (ID) : lembaga pengembangan pendidikan (LPP) UNS.

Mcdonald, P., Edwards, R.A. Greenhalg J.F.D. Morgan. C.A. 2002. Animal Nutrition. Ed ke-6. Ashford Color Pr., Gosport.

NRC. 1981. Effects of Environmental on Nutrient Requirements of Domestic Animal. National Academy Press. Washington DC.

Okoikhian CSO, Ovheruata JA, Imasuen JA, Akporhuarho OP. 2009. Physiological response of local (West African dwarf) and adapted switndzerla (white bornu) goat breed to varied climatic conditions in southsouth Nigeria. African J Agric Vol 5, No 1-6.

Okoruwa MI. Ikhimioya I. 2014. Haematological indices and serum biochemical profiles of dwarf goats fed elephant grass and varying levels of combined plantain with mango peels. American $J$ Exp Agric 4(6): 619-628.

Purwanto BP, Santoso AB, Murfi A. 1995. Fisiologi Lingkungan. Fakultas Peternakan. Institut Pertanian Bogor, Bogor (ID) Rohman A. 2010. The Effect of Altitude on Heat Tolerance Coefficient (Htc) Value And Body Weight Gain of Young Ewes Etawah Crossbred's (Ec) Goat's. Malang

Sodiq A, Abidin Z. 2002. Kambing Peranakan Ettawa Penghasil Susu Berkhasiat Obat. Jakarta (ID) : Agromedia Pustaka.

Silanikove N. 2000. Effects of heat stress on the welfare of extensively managed domestic ruminants: a review. Livest Prod Sci. 67:1-18.

Smith JB. Mangkoewidjojo S. 1988. Pemeliharaan, Pembiakan dan Penggunaan Hewan Percobaan di Daerah Tropis. Jakarta (ID) : UI Press.

Spiers DE. Spain JN. 2004. Use of physiological parameters to predict milk yield and feed intake in heatstressed dairy cows. J Therm Biol. 29:759-764.

Steel RDG. Torrie JH. 1995. Prinsip dan Prosedur Statistika Suatu Pendekatan Biometri. Ed ke-2. Terjemahan Bambang S. Jakarta (ID) : PT Gramedia Pustaka Utama. 
Sunagawa, K., Arikawa, Y. Higashi, M. Matsuda, H. Takahashi, H. Kuriwaki, Z. Kojiya, Z. Uechi S. Hong, F. 2002. Direct effect of a hot environment on ruminal motility in sheep. AsianAustalasian J. Anim. Sci., 6: 859-65.

Sudarman, A. Ito. T. 2000. Effects of dietary protein sources and levels on heat production and thermoregulatory responses of sheep exposed to a high ambient temperature. Asian-Aus. J. Anim. Sci. 13 (11): 1523-1528.

Utomo B, Miranti DP, Intan GC.2009. Kajian termoregulasi sapi perah periode laktasi dengan introduksi teknologi peningkatan kualitas pakan. Seminar nasional teknologi peternakan dan veteriner. Balai pengkajian teknologi pertanian jawa tengah

Yani A. Purwanto BP. 2006. Pengaruh iklim mikro terhadap respons fisiologis sapi peranakan Fries Holland dan modifikasi lingkungan untuk meningkatkan produktivitasnya (ulasan). Med Pet. $1: 35-46$.

Yusuf MK. 2007. Physiology Stress in Livestock. Florida (US) : CRC Press, Inc. Boca Raton.

Winarni A. 2014. Pemberian tepung daun saga rambat dan kemuning terhadap kecacingan pada kambing Peranakan Etawah laktasi. Skripsi. Sekolah Pascasarjana Fakultas Peternakan. Institut Pertanian Bogor. Bogor (ID).

Wodzicka T.M., Mastika I.M. Djajanegara A. Gardiner S. dan Wiradaya T.R. 1993. Produksi Kambing dan Domba di Indonesia. Universitas Sebelas Maret Press. Surakarta. 